\title{
Field level farm practices for calf rearing by dairy farmers in Palus tahsil of Sangli district of Maharashtra state (India)
}

\author{
P.V. PATIL AND M.K. PATIL
}

\begin{abstract}
The present study was carried out in 10 selected villages of Palus tahsil of Sangli district of Maharashtra state. A total of 100 farmers were selected for this study. Out of which 50 farmers owning less than 5 numbers of farm animals and 50 farmers owning more than 5 farm animals were selected for the present study by using proportionate random sampling method. Data were collected through personal interview schedule. Data were analyzed employing simple statistical techniques. It was observed that there was lack of adequate scientific knowledge in overall all calf rearing managemental practices, only few of the farmers were adopted scientific managemental practices. It is concluded that effective calf rearing programme definitely makes dairy farming more profitable, but there is need of percolation of scientific knowledge and package of practices regarding calf rearing upto farmers doorstep for further development of dairy farming.
\end{abstract}

KEY WORDS : Dairy farmers, Field level, Calf rearing

How to CITE THIS PAPER : Patil, P.V. and Patil, M.K. (2014). Field level farm practices for calf rearing by dairy farmers in Palus tahsil of Sangli district of Maharashtra state (India). Res. J. Animal Hus. \& Dairy Sci., 5(2) : 161-162.

M.K. Patil, Cattle Breeding Farm, College of Veterinary and Animal sciences, 